\title{
EFFECT OF PHOENIX DACTYLIFERA L. VARIETY SEWI (DATE PALM) DIFFERENT EXTRACTS ON FERTILITY OF MALE ALBINO RATS
}

\author{
M. S. Hifnawy*, M. A. Selim*, A. A. M. El-Gendy ${ }^{* *}$ and. H. M. Abdel- \\ Azeem $^{* * *}$ \\ * Pharmacognosy Dept., Faculty of pharmacy, Cairo University. \\ ** Pharmacology Dept., Faculty of Veterinary medicine, Beni-Suef University. \\ *** Pharmacognosy Dept., Faculty of pharmacy, Beni-Suef University
}

\begin{abstract}
The effect of different date palm extracts (pollen grain, leaves, fruits and pits) on male fertility was investigated. Eighty one adult male rats were classified into nine groups and were given $500 \mathrm{mg} / \mathrm{kg}$ b. wt. of each extract daily for 65 successive days. The body and sex organs weight, sperm motility percentage, sperm count, live sperm percentage, sperm abnormalities, serum ALT, creatinine, FSH, LH, testosterone and histopathological studies were evaluated after 65 days post-administration. The obtained results revealed that different extracts induced significant increase in body weight. Alcoholic, watery of pollen grains, watery fruits and watery pits extracts caused significant increase in sperm motility, sperm count, live percentage, while sperm abnormalities were decreased .Also significant increase in serum FSH ,LH and were recorded testosterone. The alcoholic and
\end{abstract}


watery extracts fruits of reduced the level of ALT. Date palm extracts

could be used to enhance male fertility without adverse effect.

\section{INTRODUCTION}

There are many ancient records of herbal medicinal plants. The use of herbal medicine has become increasingly popular worldwide. Many reviews of using date palm in folk medicine for treatment of both male and female infertility. Many date palm organs as pollen grains, fruits, leaves and pits could be of pharmacological importance. A suspension of Phoenix dactylifera date palm pollen grains was widely used as a folk remedy for curing male infertility in traditional medicine (Mirheydar, 1992 and Zargari, 1999). The male flowers of date palm were eaten directly by peoples to enhance fertility. There are reports that date palm pollen grains possess gonad stimulating activity (Soliman and Soliman, 1958 and El-Ridi et al., 1960). Also improve fertility in male rats (Bahmanpour et al., 2006) were recorded. Date palm fruits possess gonadotrophic activity in male rats (El-Mougy et al., 1991). Date palm pits possess growth promotor action by increasing body weight gain and deposition of back fat in sheep (Elgasim et al., 1995). Date palm pits increase body weight, testicular weight, serum level of LH and testosterone in male rats (Ali et al., 1999). Date flesh and pits exert hepatoprotective effect against carbon tetrachloride hepatotoxicity in rats (Al-Qarawi et al., 2004).

Thus, the aim of the present study is to investigate the effect of different date palm extracts (pollen grains, fruit, leaves and pits) on fertility of male rats for potential use in treatment of infertility.

\section{MATERIALS AND METHODS}

\section{1- Extracts:}

$\overline{\overline{\text { Kafrelsheikh Vet. Med. J. Vol. } 5 \text { No. } 1 \text { (2007) }}}$ 
Pollen grains, leaves, fruits and pits of Phoenix dactylifera L., were used in this study. They were collected from certain farms of Beni-Suef governorate, Egypt.

a) Alcoholic extracts: Alcoholic extract of each plant organ was prepared by macerating $100 \mathrm{~g}$ of each of powdered pollen grains, leaves, fruits or pits (date stones) in successive portions of ethanol (95\%) till exhaustion. The alcoholic extract in each case was evaporated under reduced pressure to obtain a semisolid residues. Extracts of pollen grains, leaves, fruits and pits were dissolved as $20 \%$ in distilled water containing few drops of Teween 80 were prepared.

b) Aqueous extracts: They were prepared by boiling $100 \mathrm{~g}$ of each of the powdered pollen grains, leaves, fruits or pits (date stones) in distilled water. The aqueous extracts were dried by evaporation in rota vapour. The residues were freshly dissolved as $20 \%$ in distilled water before use.

\section{2- Experimental animal}

a- Albino mice of 18-20 g body weight.

b- Adult male albino rats of 100-125 g body weight.

\section{Biological study:}

\section{Determination of acute median lethal dose in mice:}

Mice, 18-20 g, were administered extracts (starting with a dose of $50 \mathrm{mg} / \mathrm{kg}$ b.wt. till $7 \mathrm{~g} / \mathrm{kg}$ b.wt.). They were given orally using stomach tube. All groups of animals were observed for 24 hours for any toxic symptoms and mortality.

\section{Effect of different date palm extracts on male rat fertility:}


Eighty one apparently healthy male albino rats of 90-110 gm b.wt were used. Rats were divided into nine groups each of 9 rats. Animals were kept under hygienic measures, fed a balanced ration and water adlibitum and were left for two weeks for acclimatization before experiment. Rat dose was calculated from mice dose according to (Paget and Barnes, 1964) as $5 \mathrm{~g} / \mathrm{kg}$ b.wt. The extracts were used in $1 / 10$ this dose. The first group was given $1 \mathrm{ml}$ of distilled water containing few drops of Teween 80 and serves as control, while the other groups were given extracts at a dose of $500 \mathrm{mg} / \mathrm{kg}$ bwt. of each extract. Group II received alcoholic extract of the pollen grains, Group III received aqueous extract of the pollen grains, while group IV received alcoholic extract of the leaves and group $\mathrm{V}$ received the aqueous extract of the leaves. The group VI received alcoholic extract of the fruits, group VII received the aqueous extract of the fruits, group VIII received alcoholic extract of the pits and group IX received the aqueous extract of pits. Extracts were given orally and daily using stomach tube for 65 successive days to cover complete spermatogenic cycle.

\section{Sampling:}

Blood, semen and tissue samples were collected at 65 days postextracts administration

\section{a-Blood samples:}

Blood samples were obtained from supra-orbital venous plexus using non-heparinized microhaematocrit tube then, left to clot at room temperature, centrifuged at $3000 \mathrm{rpm}$ for 10 minutes to separate clear sera and kept in clean, dry vials in deep freezer at $-20^{\circ} \mathrm{C}$ until analysis .

\section{b-Semen samples:}


Semen was obtained by maceration of epididymis, the sperm motility, count, live percentage and total abnormalities were carried out according to Blom (1950) and Bearden and Fuquay (1980).

\section{c-Tissue samples:}

Five rats from each group (at each collection) were scarified to obtain sex organs (testes, epididymis, seminal vesicles and prostate glands). Liver and kidney were dissected out, grossly examined, accurately weighed and then fixed in $10 \%$ formalin and prepared for making paraffin sections of 5-6 u $\mathrm{m}$ thickness that ,stained with haematoxylin and eosin stain for histopathological examination (Culling, 1980).

\section{Serum biochemical analysis:}

\section{Serum alanine aminotransferase (ALT) (unit / ml):}

The serum level of ALT was determined calorimetrically according to Reitman and Frankel (1957) using transaminase kit (Bio Merieux, France).

\section{Serum creatinine (mg \%):}

Serum creatinine level was determined calorimetrically according to Siest et al (1985) using kinetic creatinine kit (BioMerieux, France).

\section{Determination of FSH, LH and testosterone hormones using radioimmunoassay.}

\section{Statistical analysis:}

Calculation of mean ,standard error as well as one way ANOVA test were carried out according to Snedecor and Cochran(1980).

\section{RESULTS}




\section{1- Determination of $\mathbf{L D}_{50}$ :}

None of the tested extracts produced any apparent behavioral changes or mortality up to 24 hour in mice at all tested doses.

\section{2- Effect on body weight:}

The obtained data revealed that body weight was significantly increased in all treated group ( $2^{\text {nd }}$ to $\left.9^{\text {th }}\right)$ week as compared to control group (Table, 1).

\section{3- Effect on male fertility:}

The effect of different date palm extracts on fertility of male was recorded (Table, 2). There was significant increase in sperm motility, sperm count, FSH, LH and testosterone. A decrease in sperm abnormalities percentage in groups treated with alcoholic pollen (II), watery pollen (III), water fruits (VII) and watery pits (IX) extracts were recorded. These were reflected by increase in weight of testis and accessory genital glands) at most treated groups as shown in Table (3).

\section{4- Effect on some liver and kidney function test:}

The obtained results revealed that watery fruits extract exerted a significant hepatoprotective and diuretic a effect. The alcoholic fruit extract exerted a hepatoprotective action, as shown in Table (2).

\section{5- Histopathological findings:}

Examination of liver, kidney and male genital system showed that rats treated with alcoholic and watery pollen grains, watery fruits and watery pits extracts nearly had similar picture. 
- liver showed normal central veins, hepatic sinusoids and hepatocytes. (fig. 1).

- Kidney showed normal cortical and medullary blood vessels and renal tubular epithelium. (fig. 2).

- Testis The seminiferous tubules were dilated with the presence of normal spermatid radial orientation.(fig. $3 \mathrm{a}$ and b).

- Epididymis Showing excessive proliferation of the layers till stage of stratification and aggregation of sperms in lumen occurred (fig. $4 \mathrm{a}$ and $b$ ).

- Prostate gland Prostate showed excessive proliferation and projected as folds in the lumen secretions (fig. 5a and b).

- Seminal vesicles Proliferation of Seminal vesicular epithelium with excessive retained secretions (fig. 6 a and b).

\section{DISCUSSION}

The present study on different date palm extracts (pollen grains, leaves, fruits and pits) revealed that all extracts exerted growth promoter action as reflected by significant increase in body weight gain begining from the $2^{\text {nd }}$ to $9^{\text {th }}$ week after administration compared to control group. This provides a base for use of different date palm organs as constituent in formulation of fattening ration in animals. Pits were used as date palm seed meal as constituent in ration of chicken, sheep, fish and rats (Kamel et al., 1981; Elgasim et al., 1995; Yousif et al., 1996 and Ali et al., 1999). 
Concerning the results of male fertility, the daily administration of $500 \mathrm{mg} / \mathrm{kg}$ b.wt of different date palm extracts for a consecutive 65 days in male rats produced an improvement in male fertility picture especially in rats treated with alcoholic and watery pollen, watery fruit and watery pits extracts.

The alcoholic and watery pollen grains treated rats showed a significant enhancement in sperm motility $76.6 \%$ and $78.2 \%$ compared to control rats $74.8 \%$. There was a significant increase in sperm count $235 \times 10^{6}$ and $248.6 \times 10^{6}$ epididymis also significant increase in percent of a live sperms $91 \%$ and $92 \%$ compared to control group $\left(196.2 \times 10^{6} /\right.$ epididymis and 86.8\%). These results were coincident with the significant increase in serum levels of FSH, LH and testosterone also with increase weight of testes, epididymis, seminal vesicle and prostate these results were confirmed to it with the histopathological picture. These results are in agreement with report of Soliman and Soliman (1958). They recorded that date palm pollen grains possess a gonad stimulating potency. Also El-Ridi et al. (1960) demonstrated that the presence of $\mathrm{FSH} \& \mathrm{LH}$ in pollen gains, cause an enlargement of seminiferous tubules containing sperms compared to control when injected into immature male rats. Similar findings were showed on using aquous pollen suspension in rats (Bahmanpour et al., 2006) as it improves sperm parameters, increases weight of testes and epididymis. This could be explained on basis that date palm contains flavonoids components (Bennet and Heftmann, 1966 and Mahran et al., 1976) that have positive effect on sperm quality (Kostyuk et al., 2004 and Vayalil, 2002). Also pollen posses gonadotrophin action, which might be due to presence of gonadotrophin like substance or steroid component present in date palm pollen (Miura et al., 2003 and Nayernia et al.,, 2004). 
Concerning the effect of fruits extracts, the watery extract was more effective than alcoholic extract resulted in significant improvement in sperm motility $(76.6 \%, 74.8)$, sperm count $\left(230.6,6.2 \times 10^{6} \%\right.$ epididymis) as well as significant increase in live percent (91.8, $86.8 \%$ )for watery fruits and control groups, respectively. These results coincident with significant increase in weight of testes, accessory genital glands and increase in serum level of FSH, LH and testosterone. These results were agreed with finding of gonadotrophic activity of watery extract date fruits palm in mature male rats that produce significant increase in FSH, LH and testosterone serum level as well as significant in weight of sex organs (El-Mougy et al., 1991). Also, the present results of inducing an increase in sperm count and motility agreed with findingthat date extract increase, G. pig sperm count and motility (Omar and Shanawany, 1986).

The present results showed that alcoholic and watery fruits extract caused significant lowering in ALT. This may serve as hepatoprotective effect. This consistent with finding of ameliorative activity of aqueous date extract on carbon tetrachloride that induce a hepatotoxicity in rat (Al-Qarawi et al., 2004) which could be explained on basis of date flavonoids and vitamine c content through inhibition P450 aromatase enzyme (Kowalska et al., 1990). Also it may play a role as hepatoprotective. Liver cytochrome P450 was significantly reduced in ascorbic acid deficient G. pigs (Rikans et al., 1978).

Concerning our the present results showed that watery pits extract induced a significant increase in sperm count $\left(238,196.2 \times 10^{6} \%\right.$ epididymis) with increase in weight of sex organs as well as increase in serum level of FSH, LH and testosterone as compared to control group 
.These findings were agreed with the report recorded that pits significantly increase level of LH and testosterone. Also increase weight of testes (Ali et al., 1999) and sperm count may be due to stimulatory effect of testosterone on testis.

We could conclude that date palm pollen grains, fruits and pits may be beneficial in treatment of infertility in albino rats. 


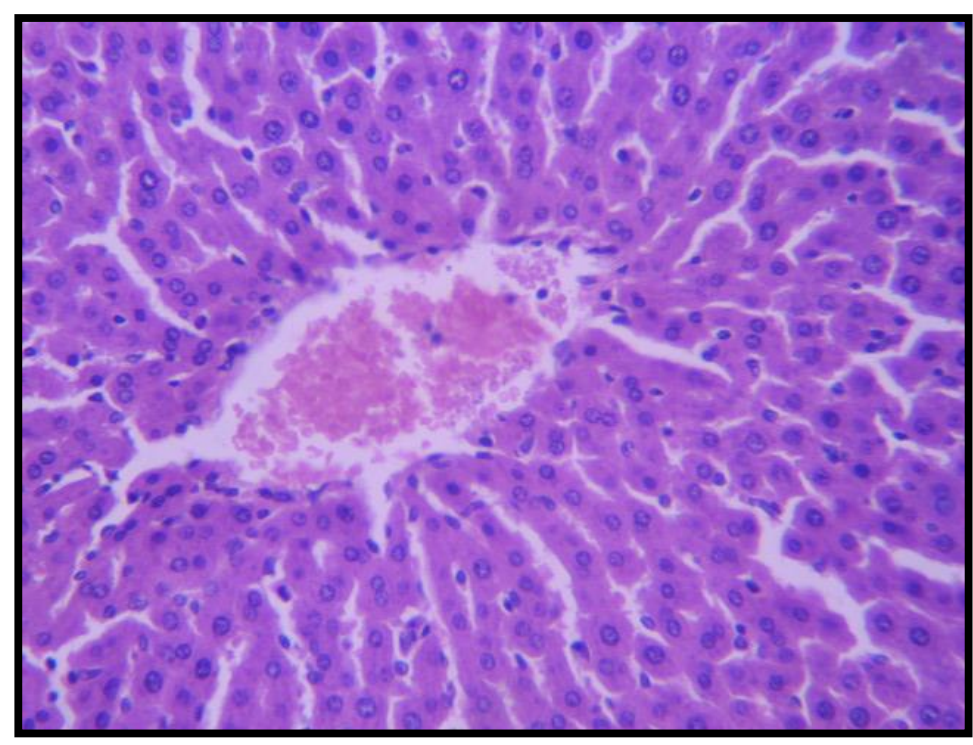

Fig.(1): Rat liver after 9 weeks Post-administration of different extracts showing no changes(H\&E x100)

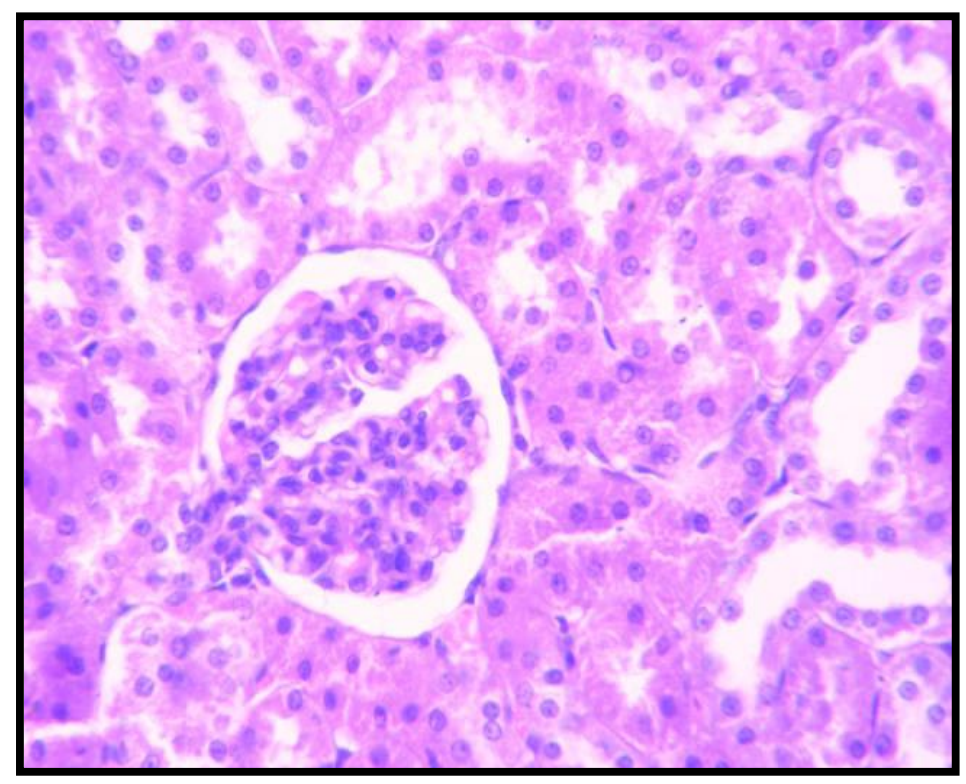

Fig.(2): Rat kidney after 9 weeks post- administration of different extracts showing no changes (H\&E x 100) 


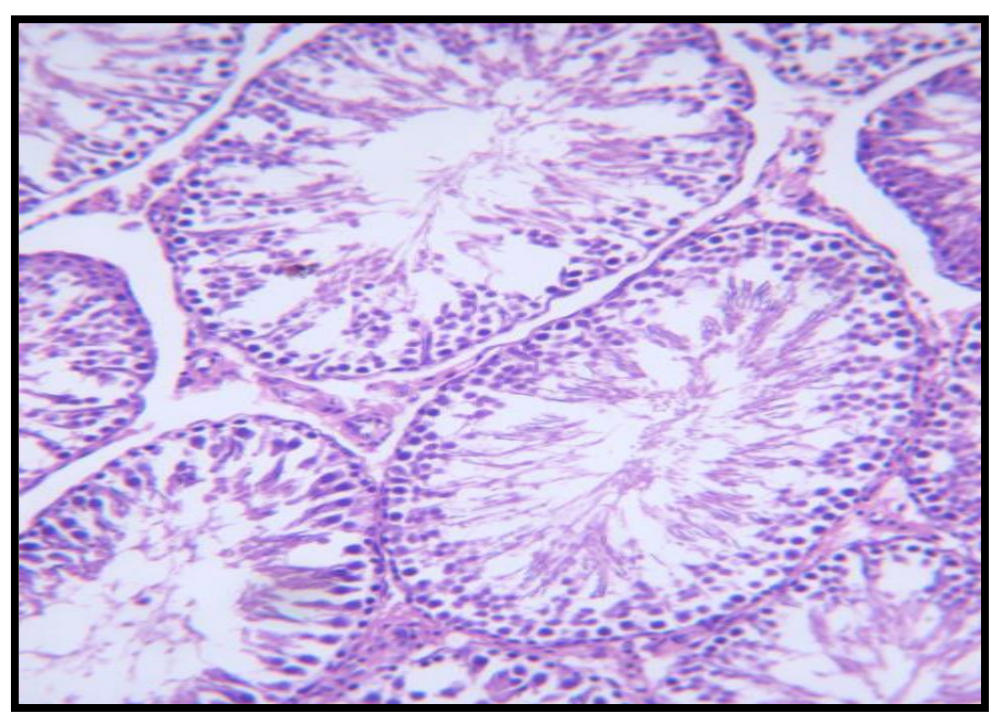

Fig. (3a): Rat testes of the control group showing the different layers of germinal epithelium (H\&E x 200)

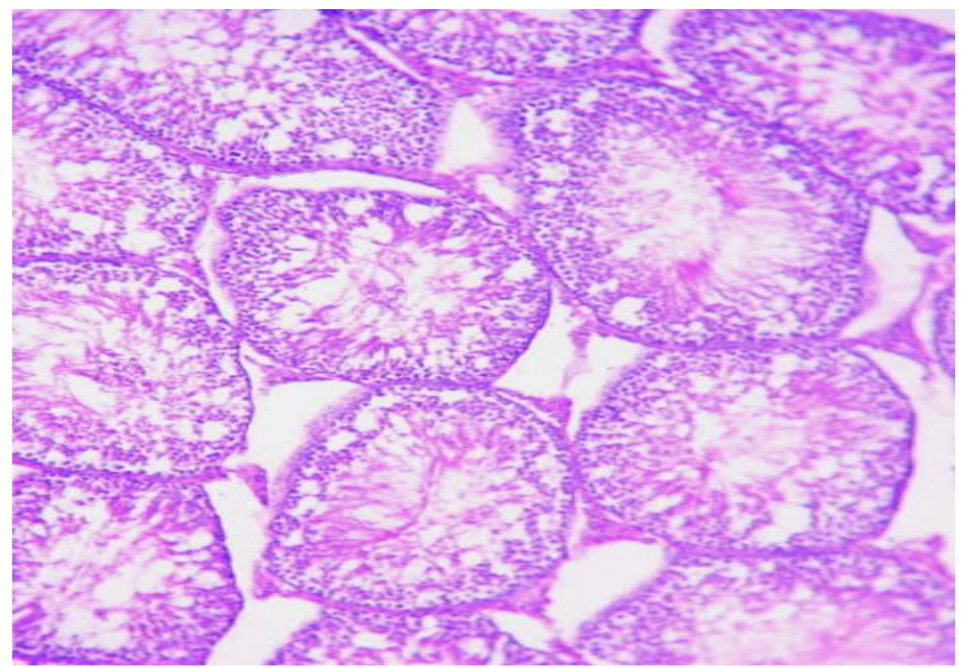

Fig. (3b): Testes of treated rat showing dialated seminiferous tubules with radial oriantation of spermatid $\mathrm{x} 200$ 


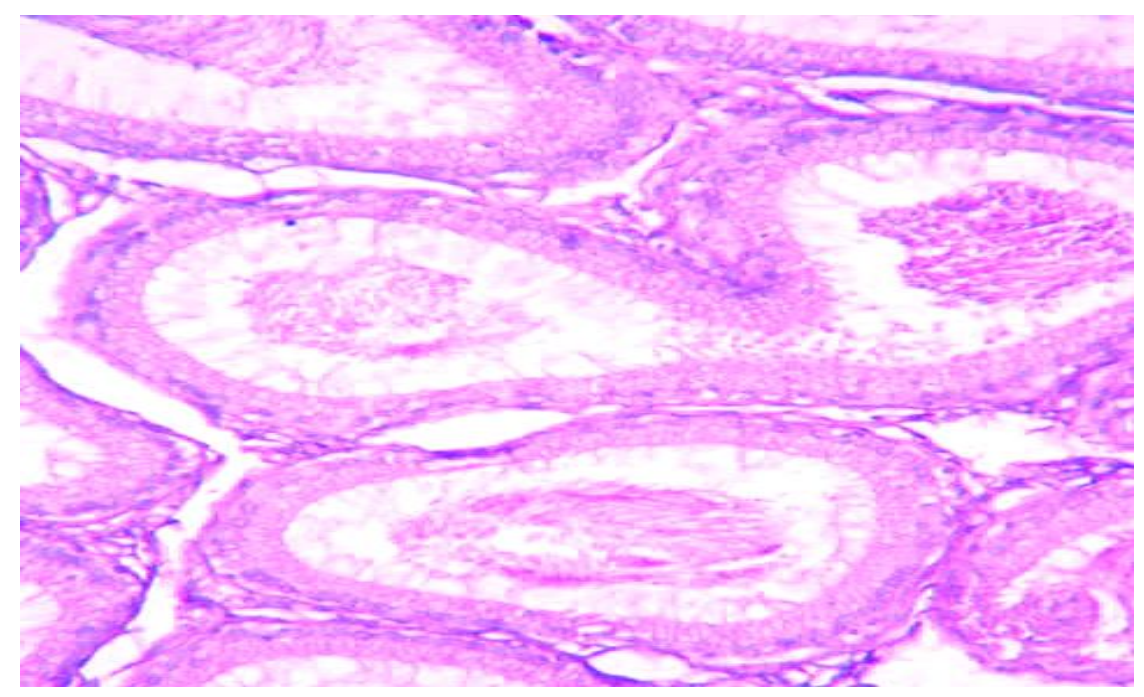

Fig. (4a): Normal epididymis of the control rat (H\&E x 200)

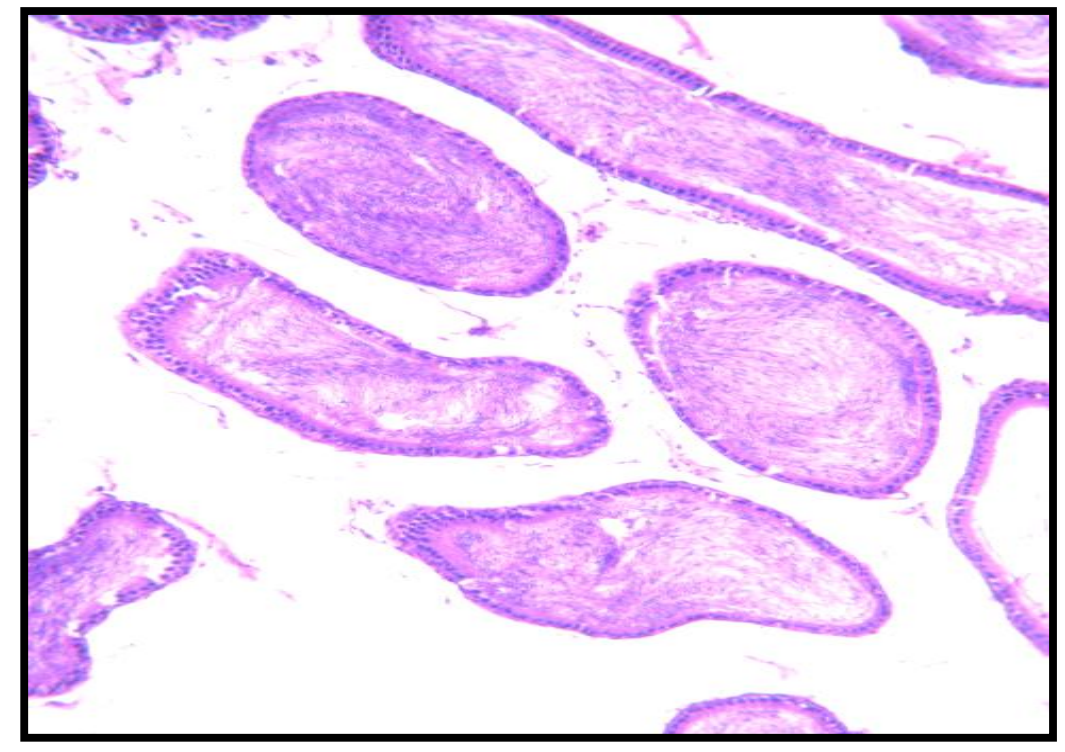

$\overline{\overline{\text { Kafrelsheikh Vet. Med. J. Vol. } 5 \text { No. } 1 \text { (2007) }}}$ 
Fig. (4b): Epididymis of treated rats showing normal structure with the presence of large number of sperms in the lumen of the duct $(\mathrm{H} \& \mathrm{E}$ x 200).

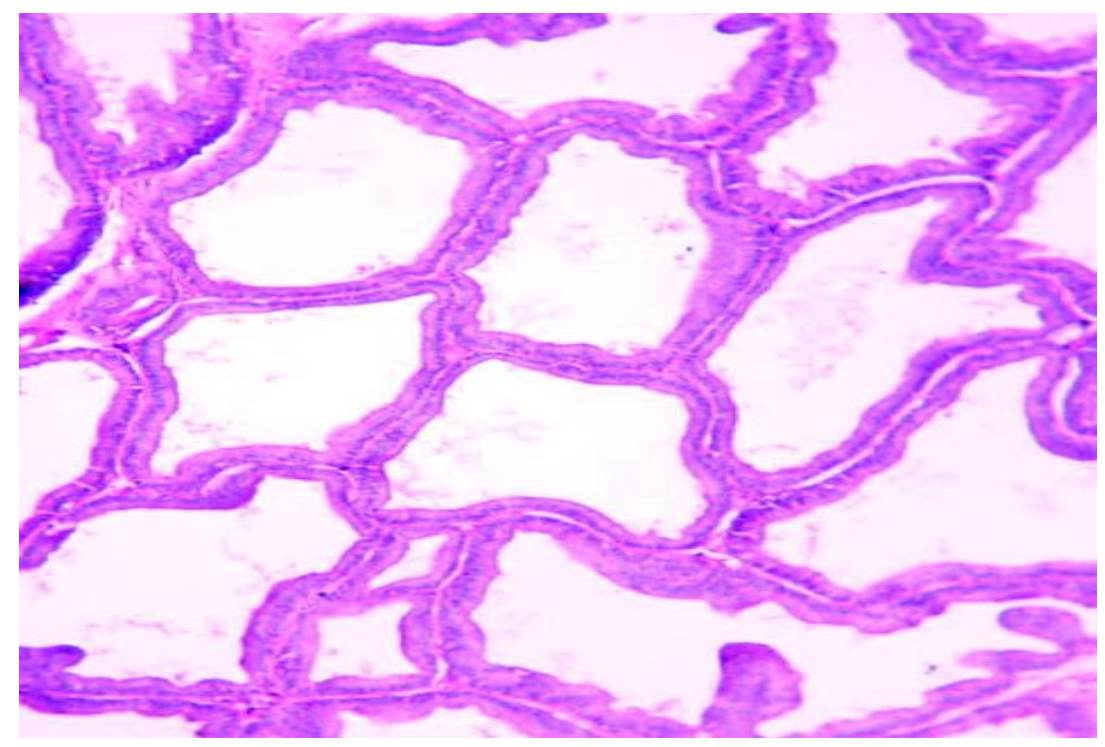

Fig. (5a): Prostate gland of control rat showing normal structure of acini (H\&E x 200).

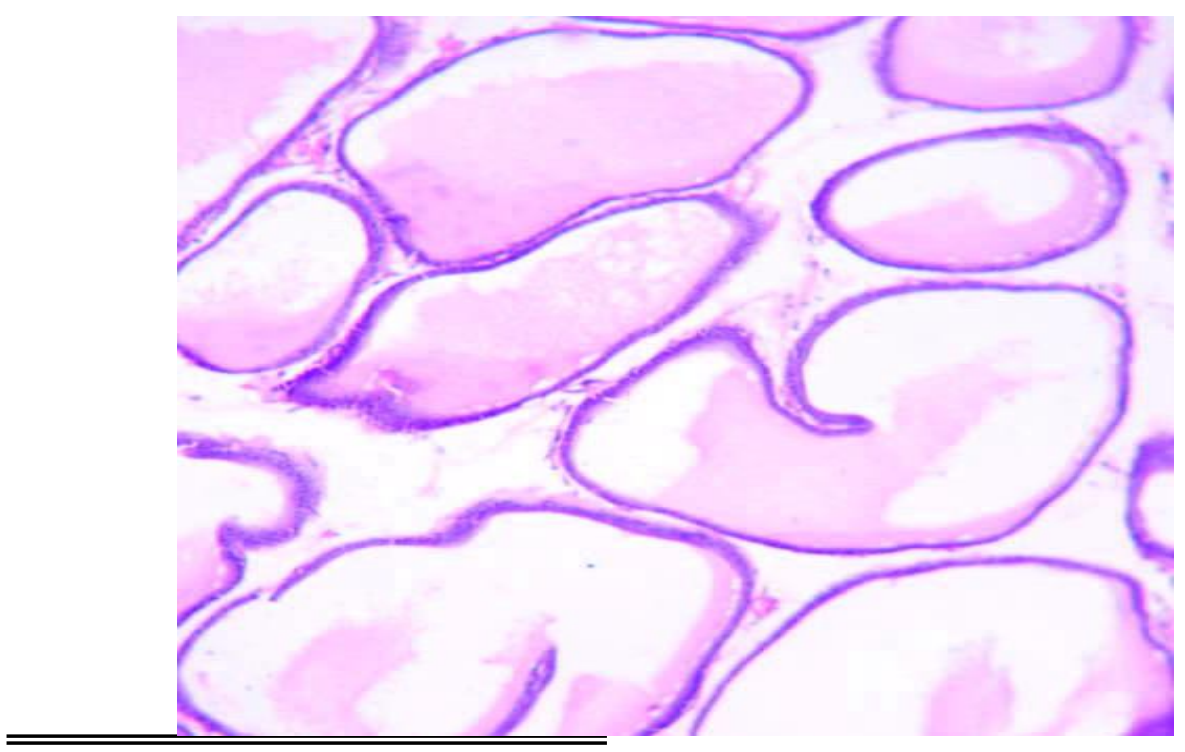

$\overline{\overline{\text { Kafrelsheikh Vet. Med. J. Vol. } 5 \text { No. } 1 \text { (2007) }}}$ 
Fig. (5b): Prostate gland of treated rat showing normal structure of acini with excessive proliferation and excessive secretion (H\&E x 200).

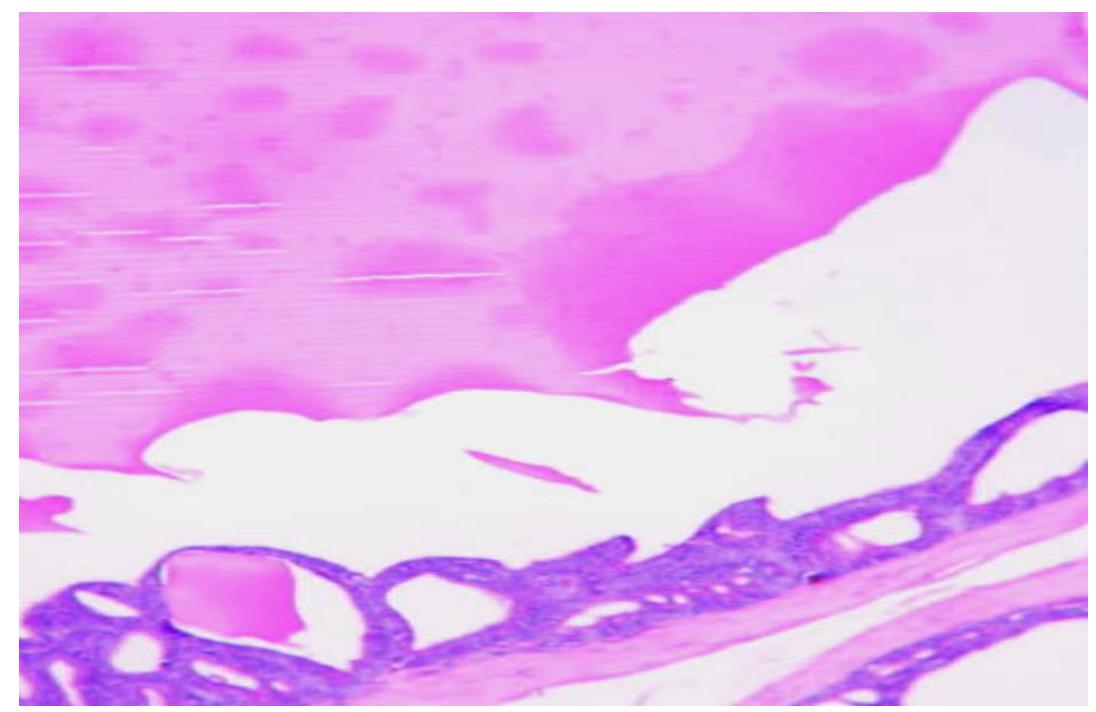

Fig. (6a): Seminal vesicles of control rat showing the normal structure of glandular tissue (H\&E x 200).

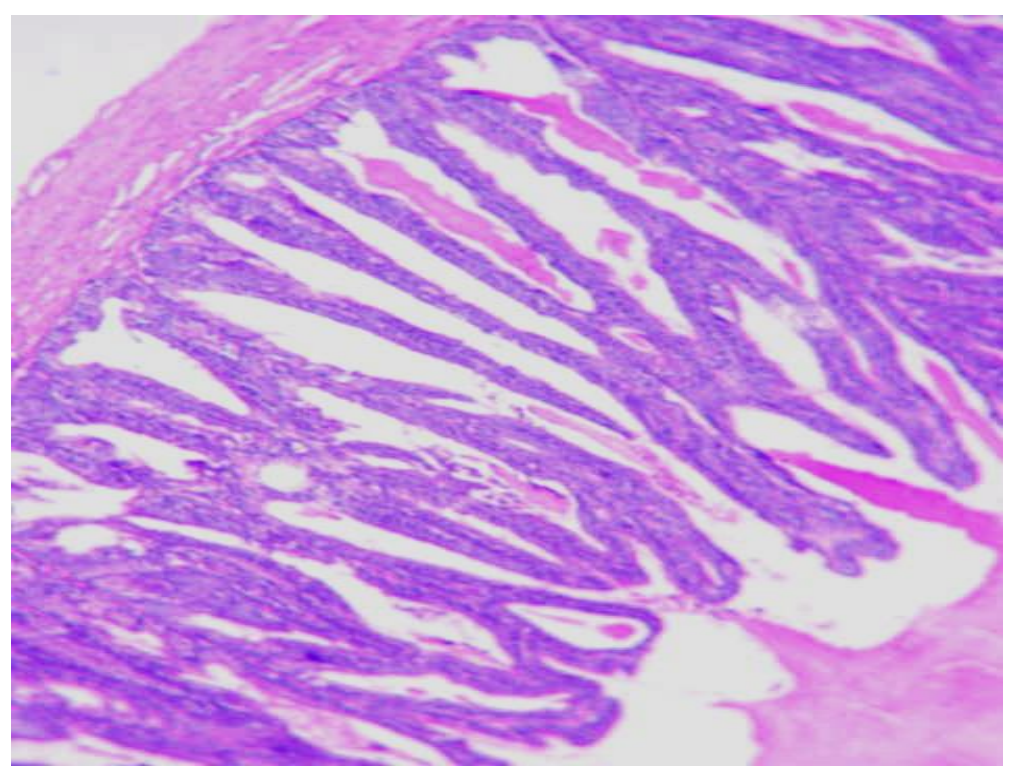

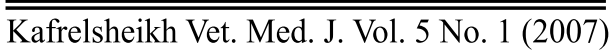


Fig. (6b): Seminal vesicles of treated rat showing the normal structure of glandular tissue and proliferation epithelium with excessive secretion retained (H\&E x 200).

\section{REFERENCES}

- Ali, B. H.; Bashir, A. K. and Alhadrmi, G. (1999): Reproductive hormonal status of rats treated with date pits. Food Chemistry. 66, 437- 441.

- Al Qarawi, A. A.; Mousa, H .M.; Ali, B . E. H.; Abdel Rhman, H. and El Mougy, S. A. (2004): Protective Effect of Extracts from Dates (Phoenix dactylifera L.) on Carbon Tetrachloride- Induced Hepatotoxicity in Rats. Intern. J. Appl. Res. Med. 2 ( 3 ) : 176- 180.

- Bahmanpour, S.; Talaei, T.; Vojdani, Z.; Panjehshahin, M.R.; Poostpasand, A.; Zareei, S.; Ghaeminia, M. (2006): Effect of Phoenix Dactylifera Pollen on Sperm Parameters and Reproductive System of Adult Male Rats . Iran J Med Sci . 31 ( 4): 208-212.

- Bearden,H J.And Fluquary,J.(1980): Applied Animal Reproduction: Restore Published Co . Inc . Reston , Virginia . P. $158-160$.

- Bennet, RD, Ko, St. and Heftmann, E.( 1966): Isolation of estrone and cholesterol from the date palm Phoenix Dactylifera. Phytochemisty 5: $231-235$.

- Blom,E.(1950): Asimple rapid staining method for the differentiation between live and dead sperm cells by means of eosin and nigrosin.Nord.Vet.Med.,2:58. 
- Culling C. (1980): Handbook of Histopathological and Histochemical Techniques $3^{\text {rd }}$.ed . Butter Work, London, Boston.

- Elgasim, E. A.; Alyousef, Y. A. and Huneida, A. M. (1995): Possible hormonal activity of date pits and flesh fed to meat animals. Food Chemistry, 52, $149-152$.

- El Mougy, S. A.; Abdel Aziz, S. A.; Al- Shanawany, M. and Omer, A. A. (1991): The Gonadotropic Activity of Palmae in Mature Male Rats . Alex., J. Pharm . Sci 5(2) :156-159 .

- El-Ridi, M.S.; El- Moety, A.; Khalifa, K. and Soliman, L. (1960): Gonadotrophic Hormones in Pollen Grains of the Date Palm. Z. Naturforschg 15 b, $45-49$.

- Kamel, B. S.; Diab, M. F.; Ilian, M. A. and Salman, A. J (1981): Nutritional value of whole dates and date pits in broiler rations. Poultry Science, 60, $1005-1111$.

- Kostyuk, V.A.; Potapovich, A.l.; Strigunova, En.; Kostyk, T. V. and Afanas'ev, I. B. (2004): Experimental evidence that flavonoid metal complexes may act as mimics of superoxide dismutase ,Arch Biochem Biophys, 428 : 204-208.

- Kowalska, M.T.; Brandt, M.E .and Puett, D. (1990): Inhibition of cytochrome p- 450 aromatase activity by plant extracts. Planta Med 56: 675 - 677.

- Maharan, G.H.; Abdel- Wahab, S.M.and Attia, A.M. (1976): A phyto-chemical study of date palm pollen. Planta Med 29: 171-175.

- Mirheydar, H. (1992): Plant Sciences. Islamic culture press. Tehran, p. $106-107$. 
- Miura, T.; Ohata,T.; Miura, C.l. and Yamauchi, K. (2003): Comple-mentary deoxyribonucleic acid cloning of spermatogonial stem cell renewal factor .Endocrinology 144 : 5504- 5510.

- Nayernia, K.; Li, M. Jaroszynski, L.; Khusainov, R.; Wulf, G.; schwandt, I.; Korabiowska, M.; Michelmann, H.W.; Meinhardt, A. and Engel, W.( 2004): Stem cell based therapeutically approach of male infertility by teratocarcinoma derived germ cells . Hum Mol Genet 13: $1451-1460$.

- Omar, A.A and Shanawany, M.M (1986): Second Date Palm Conference, Houfof, Saudi Arbia.

- Paget, G .E. and Barnes, J. M. (1964): Evaluation of drug activities and pharmacometric .Edited Lowernce and AlBachrach Chapter 6. Toxicity test .p 135 - 165 . Academic Press . London and New York.

- Reitman, S. and Frankel, S. (1957): Colorimetric method for determination serum glutamic, oxalacetic and glutamic pyruvic transaminase. Amer. J. Clin. Path 28:56 - 60.

- Rikans, L.E.; Smith, C.R. and Zannoni, V.G. (1978): Ascorbic acid and cytochrome p. 450 .J. pharmacol. Exp Ther $204: 702-705$.

- Siest,G.;Henny,J.; Schiel, F. and Young, D.S (1985): Colorimettric determination of creatinine. Interpertation of clinical laboratory tests $3^{\text {rd }}$. ed ., London.

- Soliman, F.A. and Soliman,A. (1958): The gonad stimulating potency of date palm pollen grains . Experientia, 14, (3): 9293. 
- Snedecor, G. and Cochran, W. (1980): Statistical methods. $7^{\text {th }}$.ed. Iowa, State University. Press Amer Iowa . USA.

- Vayalil, P.K. (2002): Antioxdiant and antimutagenic Properties of aqueous extract of date fruit (Phoenix dactylifera $L$. Arecaceae) J Agric Food Chem., 50 : 610 - 617.

- Yousif,O.M.;Osman,M.F., and Alhadrami, G. A.( 1996): Evaluation of dates and date pits dietary ingredients in Tilapia diets differing in protein source. Bioresources Technolology, 57, 81-85.

- Zargari, A.( 1999): Medical Plants .University of Tehran Press , Vol. 3. Tehran. p. 33- 40.

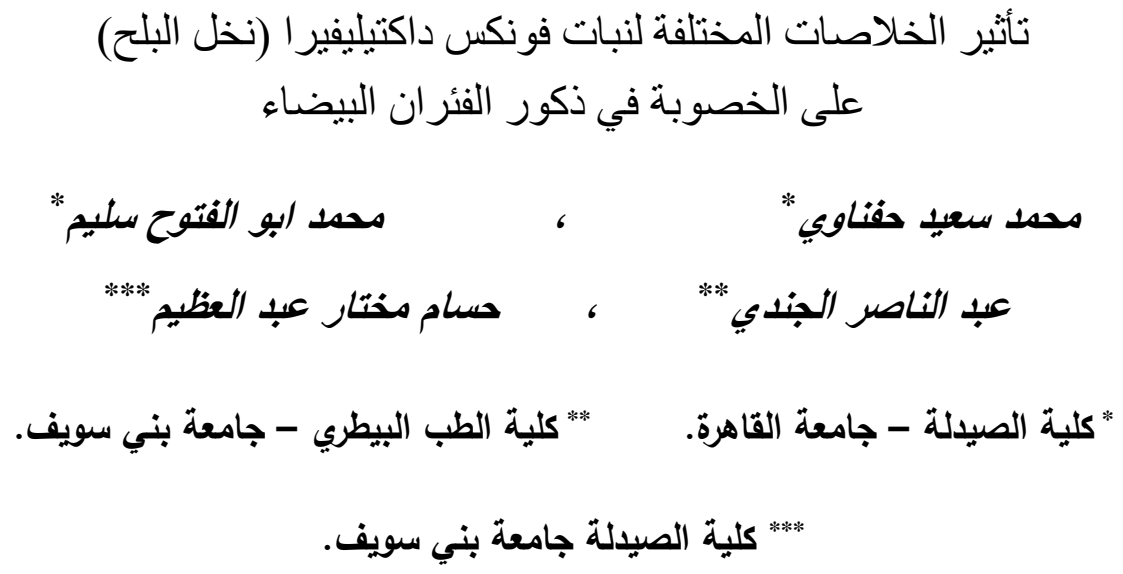

وقد أجريت هذه الدراستلبحث تأثير الخلاصـات المختلفة لبنـات نخل البلح (طلع النخل ، الأوراق ، البلح ، والنوي) علي الخصوبة في واحد وثمانون فأر"ا حيث تم تقسيمها الي تسع مجاميع بكل منها 9 فئران. ثم تم تجريع الفئران بجرعة 500 مجم / كجم من وزن الجسم عن طريق الأنبوب

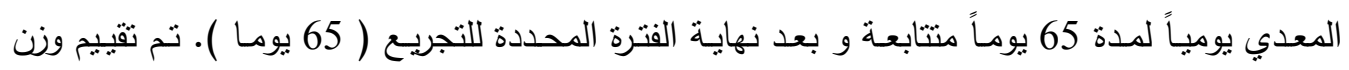


الجسم و وزن الأعضاء النتاسلية ونسبة حركة الحيوانات المنوية وعددها والأشكال الغير طبيعية منها وكذلك قياس , LH,FSH الكرياتتين و ALT, والتنتوستيرون في المصل .وكذلك دراسة قطاعات من أنسجة الكبد والكلي والأعضاء التتاسلية للفئران المعالجة .

وقد أظهرت الدراسـة زيـادة معنويـة في وزن الجسم مـع معظم الخلاصـات مقارنـة بالمجموعـهـ

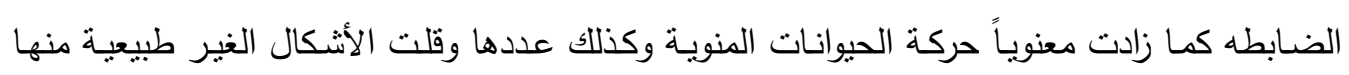
وزادت هرمونات LH,FSH والتستوتسيرون وذلك في الفئران المعالجة بالخلاصة الكحولية والمائية لطلع النخل و الخلاصة المائية لكل من البلح والنوي .

كما سبيت الخلاصة المائية والكحولية لثمار البلح انخفاض في مستوي ALT مقارنة بالمجموعة

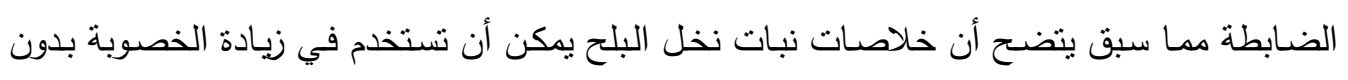
أثنار جانبية. 